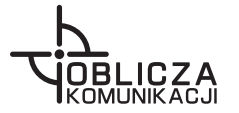

DOI: 10.19195/2083-5345.10.5

\title{
SERHIJ TROJAN
}

ORCID: 0000-0002-3053-6530

Katedra Stosunków Międzynarodowych, Informacji i Studiów Regionalnych

Narodowy Uniwersytet Lotniczy w Kijowie

\section{AŁŁA KYRYDON}

ORCID: 0000-0003-4375-5350

Katedra Stosunków Międzynarodowych

Uniwersytet Kijowski

\section{Przestrzeń informacyjna: wojna pamięci}

\begin{abstract}
Abstrakt
Z humanistycznego punktu widzenia termin „wojna informacyjna” występuje jako aktywna metoda transformacji przestrzeni informacyjnej. Chodzi o określony system (koncepcję) narzucania modelu światopoglądu w celu wywołania pożądanych zachowań, o atak na struktury tworzące informację — procesy myślenia. $\mathrm{W}$ tym sensie jedną $\mathrm{z}$ nowoczesnych odmian wojny informacyjnej jest wojna pamięci. Przejawem tych konfliktów mogą być różne sfery życia społecznego. Przykładem badania wojen pamięci stał się projekt Aleksandra Etkinda pod tytułem „Wojna pamięci. Kulturowa dynamika w Rosji, Polsce i na Ukrainie".
\end{abstract}

Słowa kluczowe: wojna informacyjna, wojny pamięci, polityka pamięci.

W niniejszym artykule posługujemy się własną definicją wojny informacyjnej. Przez termin ten rozumiemy działanie kompleksowe (zbiór operacji informacyjnych) na system państwowego i wojskowego zarządzania ze strony przeciwnika, jego wojskowo-polityczne kierownictwo, które już w czasie pokoju prowadziłoby do przyjęcia korzystnych rozwiązań dla strony (inicjatora) wpływu informacyjnego, a w czasie konfliktu całkowicie sparaliżowałoby funkcjonowanie infrastruktury zarządzania przeciwnika.

Wcześniej zamiast terminem wojna informacyjna posługiwano się innym — wojna psychologiczna. Po raz pierwszy zastał on użyty w 1920 roku przez brytyjskiego historyka Johna Fullera, który analizował wydarzenia pierwszej wojny światowej. Angielskim odpowiednikiem tego pojęcia była wojna polityczna. Później pojawił się termin psychologiczne operacje. Po raz pierwszy w dokumencie zastosował go kapitan (następnie kontradmirał) Eduard Zacharias. To pojęcie od 1957 roku zaczęło 
być wykorzystywane w amerykańskich dokumentach oficjalnych, ponieważ dało możliwość zastosowania odpowiednich narzędzi w sytuacji braku dużych operacji wojskowych. Można było używać go nie tylko w stosunku do wrogów, lecz także do krajów neutralnych lub nawet sojuszników. W Akademii Sił Powietrznych w USA od 1967 do 1968 roku prowadzono odpowiedni kurs w tym zakresie. Od 1974 roku w tej samej szkole wznowiono szkolenie oficerów strategii oraz taktyki operacji psychologicznej, jej planowania i prowadzenia.

Pojęcie wojna informacyjna pojawiło się jeszcze w połowie lat osiemdziesiątych $\mathrm{XX}$ wieku, w momencie gdy po zakończeniu kolejnej fazy zimnej wojny przed siłami zbrojnymi USA pojawiły się nowe zadania. Było ono często używane w prasie po zakończeniu operacji „Desert Storm” w 1991 roku, kiedy po raz pierwszy zastosowano nowe technologie informacyjne jako środek akcji bojowych. Oficjalnie tego terminu po raz pierwszy użyto $\mathrm{w}$ dyrektywie (nr 3600) ministra obrony USA $\mathrm{z}$ dnia 21 grudnia 1992 roku. W lutym 1996 roku ministerstwo obrony USA wprowadziło w życie „Doktrynę walki z systemami zarządzania”. Zawierała ona zasady walki $\mathrm{z}$ systemami zarządzania jako stosowanie wojen informacyjnych $\mathrm{w}$ dziedzinie wojskowej. W październiku 1998 roku ministerstwo wprowadziło „Jednolitą doktrynę operacji informacyjnych", w której użyto pojęć wojna informacyjna oraz operacja informacyjna. W brytyjskiej wersji wojna informacyjna została zdefiniowana jako „oddziaływanie na systemy informacyjne przeciwnika przy jednoczesnej ochronie własnych" (cyt. za: Denning 2002: 11).

Jednak dwie zupełnie różne sfery funkcjonowania informacji - humanistyczna i techniczna - określają dwa warianty interpretacji terminu wojna informacyjna. W humanistycznym sensie wojna informacyjna jest rozumiana jako aktywne metody transformacji przestrzeni informacyjnej. Chodzi o określony system (koncepcję) narzucania modelu światopoglądu w celu zapewnienia pożądanych typów zachowań, $o$ atak na struktury tworzące informację - procesy myślenia.

Jedną z nowoczesnych odmian wojny informacyjnej są wojny pamięci. Zwycięzcą takich wojen informacyjnych staje się ta strona, która w pełni potrafi sprofilować zachowanie przeciwnika $\mathrm{w}$ różnych sytuacjach, określić własny algorytm postępowania i zrealizować go, zwłaszcza poprzez skuteczne oddziaływanie na opinię publiczną. Najbardziej kompleksowe modelowanie zachowania przeciwnika oznacza zebranie jak największej liczby wiadomości, a następnie przechowywanie oraz przetworzenie informacji o nim, $\mathrm{z}$ uwzględnieniem wiedzy i rozumienia jego historii, kultury, religii, obyczajowości itp.

Naszym zdaniem wojny pamięci to odmiana konfliktów pamięci: zderzenie interesów poszczególnych grup, wspólnoty czy wspólnot na gruncie różnych interpretacji obrazów przeszłości. Wojny pamięci - ze względu na klasyczną definicję wojny przeciwników - nie istnieją w rzeczy wistości. Termin ten wykorzystuje się w metaforycznym sensie. Jest wprowadzony do naukowego dyskursu w celu intensyfikacji napięcia, przeciwstawienia stron konfliktu, aby bronić różnych modeli pamięci. Te wojny nie mijają gwałtownie, lecz trwają w czasie i na określonym obszarze. 
Wojny pamięci mają co najmniej trzy wymiary — historyczny, polityczny oraz społeczno-mentalny (socjopsychologiczny). Areną konfliktów mogą być różne dziedziny życia społecznego. Konflikty mogą opierać się m.in. na socjalnych, etnicznych, politycznych, ekonomicznych, tradycyjnych, językowych, religijnych oraz ideologicznych zasadach. Przeważnie wojny pamięci powstają w społeczeństwach czy wspólnotach, które zaznały krzywdy: wojny pamięci z reguły konstruowane są na fundamencie przemocy czy urazu z przeszłości. Jednak złożoność sytuacji wynika z nałożenia się starych i nowych - indywidualnych oraz zbiorowych - obaw (leków, uprzedzeń) zachowanych w pamięci. Wskutek takiego przenikania kształtuje się skomplikowana wspólnota $\mathrm{z}$ dosyć wysokim imperatywem pamiętania.

Spory o pamięć (wojna pamięci) często są obciążone nadmiernymi emocjami stron biorących udział w konflikcie i potrzebują przezwyciężenia pewnych psychologicznych barier oraz zmiany asocjacji. Przyczyny rozwoju tych sporów powiązane są przede wszystkim z aktywizacją postrzegania różnych wersji przeszłości. Są one uwarunkowane wielością oraz niejednoznacznością interpretacji tej przeszłości w różnych społeczno-politycznych warunkach i doświadczeniem nabytym podczas transformacji historycznych. Powstaniu wojny pamięci może służyć: oficjalna retoryka, naruszenie tradycji, polityka kulturalna, urbanistyka, toponomastyka (w szczególności nazwy obiektów miejskich), regionalne osobliwości, skomplikowana historia i wiele wariantów jej objaśniania (w szczególności na poziomie międzypaństwowym), historyczne narracje, stereotypy, symbole, pogrzeby, pomniki i inne oznaki upamiętnienia.

Dla zrozumienia charakteru i przyczyn wdrażania wojen pamięci znaczące wydają się rozważania amerykańskiego historyka Williama Sewella, dotyczące oceny poszczególnych zdarzeń, które wpływają na charakter trwałych wzorców zachowania (zmieniają charakter percepcji lub odporność charakterystyk behawioralnych), a także ich interpretację. Sewell traktuje wydarzenie jako takie, które w swojej podstawie ma znaczenia i określa zmiany w systemach znaczeń. Dlatego aktualizuje się konieczność analizy wpływu przeszłych wzorców kulturowych na teraźniejszość:

Historyczne - według skali - wydarzenia są niezbędne do analizy teoretycznej ze względu na to, że one zmieniają bieg historii, zadając nieprzewidywalne kierunki postępu rozwoju społecznego i zmieniając kazualną oś interakcji społecznych. (Sewell 2005: 221)

Badacz podkreśla potrzebę oceny zdarzenia, biorąc pod uwagę kontekst i zdobywanie nowych znaczeń poprzez siłę rozwoju. Na uwagę zasługuje teza autora, że wydarzeniom właściwe jest zjawisko inertności (path dependency) - wydarzenia z przeszłości mają wpływ na przyszłe zdarzenia. Aktualizacja konkretnego zdarzenia (przede wszystkim chodzi o znaczące wydarzenie historyczne, które wpłynęło na przebieg rozwoju społecznego) jest markerem aktualizacji znaczeń i sensów rozwoju kultury i społeczeństwa. Badacz podkreśla, że wydarzenia w swojej podstawie są obdarzone sensami i określają przemiany w systemach znaczeń. Wybór i tworzenie symboli wydarzeń godnych pamięci odbywają się za pośrednictwem interesów wielu grup wpływu (Sewell 2005: 221). 
Jednak należy pamiętać, że między wydarzeniem, relacjami naocznych świadków oraz interpretacjami zdarzeń istnieje znaczna odległość. Świadectwo lub interpretacja zdarzeń, odtwarzanie wiedzy itp. stanowią część danej ramy interpretacji, która z kolei jest określana poprzez system wartości i praktyki dyskursywne, semiotyczne mechanizmy i konfigurację stosunków między powiązaniami wewnątrz władzy. Odległość między zdarzeniem (granicznym) i jego aktualizacją w przyszłości nieuchronnie prowadzi do ścierania się, odtwarzania, a następnie do niwelowania lub do metaforyzacji następstwa zdarzeń. Na nasze postrzeganie lub odtwarzanie kolejnych zdarzeń z przeszłości lub ich reprezentacji wpływa dziedzictwo czasowego nawarstwiania się, z kolei kontekst ma wpływ na kształtowanie i reprodukcję danego zjawiska czy wydarzenia. Pamięć o wydarzeniach reanimowanej przeszłości w zasadzie nie jest jednowymiarowa: jest alternatywna, co powoduje nieporozumienia $\mathrm{w}$ interpretacji następstw.

Wojny pamięci są procesem interaktywnym, który odbywa się w teraźniejszości w związku z interpretacją wydarzeń z przeszłości. Czasowa perspektywa wymaga analizy dynamiki oraz cech rozwoju konfliktu. To z kolei warunkuje potrzebę zaznaczenia stadiów, faz jego powstawania i wdrażania w czasie, badania wskaźników dynamicznych i analizy procesów interakcji konfliktowej. W swoim rozwoju każdy konflikt przechodzi kilka stadiów, które z kolei dzielą się na fazy. Na podstawie przeglądu etnicznych konfliktów psycholog Petro Szychyriew uogólnia modelowanie konfliktów społecznych, stwierdzając:

Wszystkie one przechodzą podobną drogę. Faza pierwsza, romantyczna: dążę do zwycięstwa, mój przeciwnik jest zgnieciony, ja go zaduszę, ujarzmię, zmuszę go działać w moim interesie. Następna faza to faza apatii, gdy pojawia się poczucie, że zadanie eliminacji przeciwnika, które na początku nie wydawało się zbyt trudne, nie jest tak łatwe do wykonania. Potem następuje faza impasu - wrażenie, że pokonanie przeciwnika jest nie tylko nie proste, a nawet niemożliwe. Po tym następuje faza rozpaczy. Człowiek zaczyna rozumieć, że jego przeciwnik też chce czegoś dla siebie bardzo ważnego. Tutaj właśnie i powstaje podstawa do negocjacji. (Шихирєв 1999: 49)

Jest oczywiste, że w tym modelu ewolucji konfliktu za podstawę przyjmuje się społeczno-psychologiczny składnik konfliktu.

Zwracamy szczególną uwagę na fakt, że przy tworzeniu nowej kultury odpowiedzialnej i dialogowej pamięci międzysąsiedzkiej ważne jest uwzględnienie dyskursu etyki dialogu stosunków dwustronnych. To właśnie ona kształtuje europejską kulturę pamięci: od międzysąsiedzkiej „historii wzajemnych zdrad” (Tpa6a 2009: 56), do „wspólnych impulsów doświadczenia” (Козеллек 2006: 436), które w dłuższej perspektywie są zdolne do dekonstrukcji świadomości wypaczonych przez totalitaryzmy. Jej postulaty opierają się zwłaszcza na wzmocnieniu wspólnych pozytywnych i solidarnych punktów odniesienia, np. etosu chrześcijańskiego przebaczenia oraz cierpliwego, wzajemnego opracowania zbioru narodowych krzywd i obelg.

Modele dialogowej pracy z pamięcią kolektywną zaproponował Paul Ricoeur: model tłumaczenia, mający na celu wymianę znaczeń zawartych w semantycznym 
światopoglądzie każdej kultury i przestrzeni, w której określa się jej pamięć; model wymiany pamięci, mający na celu przyjęcie historii „drugiego” i jej uznanie; model przebaczenia - skierowany na wspólny przegląd pamięci o przeszłości w celu konstruowania dyskursu miłosierdzia i wzajemnego współczucia. Pamięć, zdaniem Pierra Nory, przestaje być „zbiorem elementów przeszłości, które należy pamiętać, aby przygotować grunt dla pożądanej przyszłości; ona staje się sposobem uświadomienia sobie własnej teraźniejszości" (Hopa 2010: 5).

Spostrzeżenia te potwierdza niemiecki badacz Herald Weltzer, który twierdzi, że gdyby przeszłość była tylko historią, byłaby zamrożona i nie bolała. Faktycznie, w przeszłości jest mniej przeszłości, niż wielu się wydaje. Jednak to właśnie z powodu minionych wydarzeń dochodzi do konfliktów, bitew lub wojen pamięci (Вельцер 2005: 28).

Przykładem badania wojen pamięci stał się projekt Aleksandra Etkinda pod tytułem „Wojna pamięci. Kulturowa dynamika w Rosji, Polsce i na Ukrainie/A Memory War: Cultural Dynamics in Russia, Poland and Ukraine”, zakładający zbadanie polityki pamięci na Ukrainie, w Rosji i w Polsce ${ }^{1}$. Jego realizacja rozpoczęła się 1 października 2010 roku i trwała do 31 września 2013 roku. Metodologiczne podstawy projektu opierały się na krytycznych i analitycznych praktykach współczesnych dyscyplin humanistycznych, a jego zadaniem było badanie wpływu pamięci zbiorowej oraz wyobrażeń o traumatycznych wydarzeniach XX wieku na rozwój wschodnioeuropejskich wspólnot narodowych. Głównie koncentrowano się na: zdarzeniach pamięci w przestrzeni transnarodowej, języku pamięci w Rosji i na Ukrainie, korzyściach i krzywdach historycznych w polityce tożsamości w Europie Wschodniej, sile polityk pamięci w Europie Wschodniej: sekurytyzacji z dziedzictwem komunizmu w Polsce, Rosji i na Ukrainie, imperializmie męczeństwa: cierpieniu i pamięci w polskich, rosyjskich i ukraińskich filmach i powieściach ${ }^{2}$.

W ramach tego projektu naukowcy oraz politycy patrzyli na kulturalne i polityczne transformacje w Europie Wschodniej przez pryzmat tzw. paradygmatu okresu przejściowego: przejścia od totalitaryzmu do praktyki współczesnej demokracji liberalnej. Mieli oni za zadanie zastosowanie paradygmatu pamięci do opisu procesów transformacyjnych, generowanych traumatycznym dziedzictwem carskiej i radzieckiej przeszłości. Chcieli także zebrać jak najpełniejszy materiał, który posłużyłby do wyznaczenia przyszłych celów badawczych z zakresu badanej problematyki.

Projekt był powiązany $\mathrm{z}$ badaniem dynamiki kulturowych form pamięci, ich interakcji w Polsce, na Ukrainie i w Rosji. Musiał ustalić nową metrykę: dać nowy wymiar procesom głębokich zmian, które zaczęły się po upadku bloku radzieckiego,

${ }^{1}$ Badanie odbywało się w pięciu europejskich uniwersytetach: w Cambridge (Wielka Brytania), w Groningen (Holandia), w Bergen (Norwegia), w Helsinkach (Finlandia) oraz w Tartu (Estonia).

${ }^{2}$ Kierownik projektu A. Etkind jest rusycystą, historykiem kultury, specjalistą ds. psychoanalizy oraz teorii literatury, autorem książek, m.in.: Eros niemożliwego. Historia psychoanalizy w Rosji, Sodoma i Psyche. Szkice z intelektualnej historii Srebrnego wieku. 
a także odkryć ukryte przeszkody czyhające na narody w tym regionie i hamujące dalsze transformacje wewnątrz wspólnot narodowych na znacznie głębszym poziomie. Należy pamiętać, że choć projekt już się zakończył, jego wyniki wymagają jeszcze szczegółowej, wszechstronnej analizy i opublikowania.

Problem pamięci historycznej, bolesnych stron przeszłości jest bardzo aktualny dla społecznej i państwowej przestrzeni Europy Środkowo-Wschodniej. Innymi słowy, powołując się na słowa Pierre’a Nory, można powiedzieć, że w tej części Europy

pamięć dostarczyła historii nowego impulsu, zaktualizowała podejścia do przeszłości i przeniknęła we wszystkie okresy i zakresy badania. (Hopa 2010: 5)

Równie trafnie na ten temat wypowiedział się niemiecki naukowiec Jörn Rüsen:

pamięć zmienia czasowy status przeszłości w taki sposób, że ono, nie przestając być przeszłością, staje się wręcz teraźniejszością i otwiera perspektywę na przyszłość (Рюзен 2010: 118).

Ważne jest, aby przy tym nie dopuścić do bezpośredniej ingerencji władzy państwowej w sprawy historyków, do dyktatu dotyczącego tego, co i jak robić w sferze polityki pamięci, kogo „karać”, a kogo „ułaskawiać”, na co zwrócili uwagę przedstawiciele Stowarzyszenia „Wolność dla historii” (Liberté pour l'Histoire) w swoim słynnym „Apelu z Blois” z 11 października 2008 roku. Napisali bowiem:

Historia nie może stać się więźniem wydarzeń bieżących, nie można jej pisać pod dyktatem pamięci, które rywalizują między sobą. W wolnym kraju do kompetencji władzy politycznej nie odnosi się definiowanie prawdy historycznej lub ograniczenia wolności historyków za pomocą sankcji karnych [...] Zwracamy się do władzy publicznej, aby przekazać jej, że o ile ona jest odpowiedzialna za opiekę nad zbiorową pamięcią, o tyle ona nie musi w kategoriach prawnych instalować historycznych dogmatów, które mogą znacznie ograniczyć wolność intelektualną historyków. (cyt. za: Tpa6a 2009: 56)

Uważamy, że niezwykle ważną sprawą w kontekście analizy omawianego problemu jest podkreślenie konieczności odejścia od koncepcji pogranicza, czyli granicy interakcji i konfrontacji różnych narodów, kultur lub cywilizacji, w stronę koncepcji współpracy, jedności i budowania mostów porozumienia w tak trudnej i kontrowersyjnej dziedzinie, jaką jest pamięć zbiorowa i historyczna świadomość narodów centralnej i wschodniej Europy. Rola i znaczenie historyków — zarówno poszczególnych naukowców, jak i akademickich wspólnot oraz specjalistycznych instytucji - w tym procesie jest nie do przecenienia.

Sądzimy, że zdolność zapominania w połączeniu ze zdolnością pamiętania jest czymś innym niż umiejętność myślenia historycznego i natchnienie nią społecznej pamięci pokoleń. Umiejętność pamiętania i zapominania nie przychodzi sama, ale jest osiągana przez aktywną działalność świadomości historycznej w zakresie zrozumienia oraz przemyślenia przeszłości przez pryzmat teraźniejszości i dla przyszłości. Należy wykorzystać zdobyte doświadczenia w przyszłości, a obecny moment uznać za historyczną szansę, aby udało się to zrealizować. Konstruowanie polityki pamięci powinno opierać się nie na mitotwórczości i odrzuceniu innego punktu widzenia, lecz na możliwym maksymalnym interdyscyplinarnym badaniu całej złożoności, 
zawiłości historycznych procesów, zwłaszcza tych, które dotyczą często bardzo kontrowersyjnej wspólnej przeszłości. Taki wniosek, naszym zdaniem, jest aktualny i sprawiedliwy dla współczesnych dyskursów polityki pamięci w krajach Europy Środkowej i Wschodniej oraz realizacji w tym kontekście różnych informacyjnych i naukowych projektów badawczych.

\section{Przełożyła Iryna Procyk}

\section{Bibliografia}

Conflict and Memory: Bridging Past and Future in (South East) Europe (Southeast European Integration Perspectives) (2010): red. W. Petritsch, Wien.

Denning D.E. (2002): Wojna informacyjna i bezpieczeństwo informacji, Warszawa.

Sewell W. (2005): Logics of History: Social Theory and Social Transformation, Chicago.

Адорно Т. (2005): Что значит „проработка прошлого”, „Неприкосновенный запас” nr 2-3 (40), http://magazines.russ.ru/nz/2005/2/ado4.html (dostęp: 24.10.2017).

Бордюгов Г.Ж. (2011): „Войны памяти” на постсоветском пространстве, Москва.

Вельцер Х. (2005): История, память и современность прошлого. Память как арена политической борьбы, „Неприкосновенный запас” nr 2-3 (40-41), s. 28-35.

Волянюк О.Я. (2012): Конфлікти пам'ятей у політичному просторі: теоретичні аспекти, „Національна та історична пам’ять” 6, s. 41-60.

Друга світова війна та (від)творення історичної пам'яті в сучасній Україні, http://ww2historicalmemory.org.ua/presentation.html) (dostęp: 11.10.2017).

Захарченко Т. (2011): „Войны памяти”: Английская конференция о культурной памяти в Восточной Европе, „Новое литературное обозрение” nr 11 (11-12 марта 2011 г., http://magazines. russ.ru/nlo/2011/110/za56.html (dostęp: 24.10.2017).

Історія на фронті інформаційної війни: Круглий стіл, http://www.ukrinform.ua/ukr/news/ 1970592, dostęp: 11.10.2017.

Мінк Ж., Неймайєр Л. (2009): Європа та їі болісні минувщини, Київ.

Зверева В. (2011): Сражения за память, войны воспоминаний. Научный семинар „Война памяти: культурная динамика в России, Польше и Украине" (Кембридж, Кингс- колледж, 4-5 июня 2010 г.), „Новое литературное обозрение” nr 107.

Киридон А. (2013): „Війни пам'ятей” і моделі примирення: інтерпретація понять, [w:] Війни пам'ятей та політика примирення, ред. В.Ф. Солдатенко, Київ, s. 27-37.

Козеллек Р. (2006): Часові пласти. Дослідження з теорії історії; [Пер. з нім.]/Райнгарт Козеллек, Київ.

Нора П. (2010): Расстройство исторической идентичности, [w:] История, историки и власть: Международный круглый стол, Москва, 2 февраля 2010 г. Материалы к дискуссии, Москва, s. $1-83$.

Рикёр П. (1995): Конфликт интерпретаций. Очерки о герменевтике, Москва.

Рюзен Й. (2010): Нові шляхи історичного мислення, Львів.

Сюндюков I. (2010): Ми та Європа: гармонізація пам'яті, „День” nr 47.

Траба Р. (2009): „Другий бік пам'яті”. Історичні досвіди та їхнє пам'ятання в Центрально-Східній Європі, „Україна модерна” nr 4 (15), s. 53-62.

Шихирев П.Н. (1999): Современная сочиальная психология, Москва.

Шнирельман В.А. (2003): Войны памяти: мифыь, идентичность и политика в Закавказье, Москва. 


\section{Information space of the war memory}

Summary

In humanitarian terms, information war is an active method of transforming information space. It is about a system (concept) imposing model outlook to ensure the desired behaviors; the attack on structures that generate information - thought processes. In this sense, one of the varieties of modern information war was a war of memories. An arena of manifestations such conflicts may be different aspects of life. A striking example of research of a war of memories is Alexander Etkind's project called „A Memory War: Cultural Dynamics in Russia, Poland, and Ukraine”.

Keywords: information war, war of memories, politics of memory. 